Herbal medicines

\section{Safety of herbal medicines in children}

\section{Choonara}

\section{A commentary on the paper by Ramsay et al}

$\mathrm{H}$

erbal medicines are used extensively by children in the West. They are an important part of complementary and alternative medicines (CAM). A study of over 500 children in the southwest of England reported that almost one in four children had received CAM therapy. ${ }^{1}$ Two studies in North America reported that over $10 \%$ of children had used at least one form of CAM therapy. ${ }^{23}$

\section{EFFICACY}

It is important that health professionals adopt a non-judgemental approach with regard to parents who use CAM for their children. Many herbal medicines may be effective as we know that many plant derived chemicals are the basis of conventional drug therapies. Parents will often use a herbal medicine for their children on the basis that it is more "natural" and safer. One third of parents will use CAM because they feel that they are safer than conventional medicines! ${ }^{3}$

\section{TOXICITY}

There have been numerous studies in relation to the incidence of adverse drug reactions to children in hospitals. ${ }^{4}$ The toxicity of certain herbal medications is well recognised on the basis of case reports. ${ }^{5-9}$ The incidence of toxicity in relation to herbal drug therapy, however, is unknown. A recent systematic review of the toxicity of CAM concluded that there were insufficient data to determine the incidence of toxicity of herbal medicines. ${ }^{10}$ Table 1 gives examples and the mechanisms of toxicity.

The toxicity of herbal medicines may be due to intrinsically toxic constituents

\section{DRUG INTERACTIONS}

\section{FORMULATION} order to increase their efficacy. of the herbal ingredients. Examples of this include viscotoxins, which are constituents of mistletoe and are both cytotoxic and cardiotoxic. ${ }^{11}$ Other examples include cyanogenetic glycosides which are present in the kernels of a number of fruits. Gastric hydrolysis of these compounds results in the release of hydrogen cyanide. ${ }^{11}{ }^{12}$ Other important mechanisms associated with the toxicity of herbal medicines include allergic reactions and contamination by heavy metals.

It is important to appreciate that herbal medicines may interact with prescribed medicines. Concurrent use of herbal or homeopathic remedies alongside prescribed or over the counter medicines is frequent. ${ }^{3}$ Drug interactions are a significant problem in association with the use of St John's wort. ${ }^{11}{ }^{13}$ St John's wort may induce drug metabolising enzymes within the liver as well as possibly affecting P-glycoprotein, which is a transport protein present throughout the body. ${ }^{113}$

The paper by Ramsay and colleagues highlights the important issues in relation to the formulation of herbal medicinal products. ${ }^{14}$ The Medicines Control Agency has expressed concerns regarding the variable quality of unregulated herbal products. ${ }^{11}$ The paper by Ramsay et al, however is highly suggestive that potent corticosteroids have been deliberately introduced to herbal creams in

Unfortunately inappropriate formulation development is not restricted to complementary therapies. In 1937, 76

Table 1 Toxicity associated with herbal medicines

\begin{tabular}{|c|c|c|}
\hline Herbal product & Mechanism of toxicity & Toxicity \\
\hline $\begin{array}{l}\text { Tibetan Herbal Vitamin } \\
\text { Jin Bu Juan }\end{array}$ & $\begin{array}{l}\text { Contamination with lead } \\
\text { Incorrect plant used } \\
\text { (genus stephania not polygala) }\end{array}$ & $\begin{array}{l}\text { Seizures, developmental delay, anaemia } \\
\text { Respiratory depression, bradycardia, } \\
\text { CNS depression }\end{array}$ \\
\hline Neem tree oil & $\begin{array}{l}\text { Incorrect route (given orally } \\
\text { instead of topically) }\end{array}$ & Encephalopathy \\
\hline Various traditional & $\begin{array}{l}\text { Direct toxicity of herbal product } \\
\text { (contain pyrrolozidine alkaloids) }\end{array}$ & Hepatic veno-occlusive disease \\
\hline $\begin{array}{l}\text { Wau wa cream } \\
\text { St John's wort }\end{array}$ & $\begin{array}{l}\text { Adulteration of product } \\
\text { Induction of drug metabolism } \\
\text { leading to drug interaction }\end{array}$ & $\begin{array}{l}\text { Corticosteroid toxicity } \\
\text { Depends on drug (often loss of } \\
\text { therapeutic effect) }\end{array}$ \\
\hline
\end{tabular}

Americans, many children, died following the preparation of a sulphonamide solution in $72 \%$ diethylene glycol. ${ }^{15}$ These deaths resulted in legislative changes in the USA to ensure that the quality of medicines was formally assessed.

In many developing countries medicines are available in street markets and the source of the medicines is unknown. Forty seven children died in Nigeria following the deliberate use of diethylene glycol as a solvent for paracetamol instead of propylene glycol. ${ }^{16}$ There have been similar tragedies affecting children in Bangladesh and Haiti. ${ }^{17}{ }^{18}$

It is important that the quality of herbal medicines is significantly improved. This can only be achieved by parents, health professionals, and regulatory authorities working in conjunction with the suppliers of herbal therapies to ensure that they are of sufficient standard. Prosecution of suppliers who deliberately adulterate herbal creams is urgently required. Parents who wish to use herbal medicines should try to obtain them from reliable sources-that is, one of the main herbal practitioner associations. ${ }^{14}$

Arch Dis Child 2003;88:1032-1033

Correspondence to: Prof. I Choonara Academic Division in Child Health, University of Nottingham, Derbyshire Children's Hospital, Uttoxeter Road, Derby DE22 3NE, UK; Imti.choonara@nottingham.ac.uk

\section{REFERENCES}

1 Simpson N, Pearce A, Finlay F, et al. The use of complementary medicine by children. Ambul Child Care 1998:3:351-6.

2 Spigelbatt L, Laine-Ammara G, Pless B, et al. The use of alternative medicine by children. Pediatrics 1994;94:811-14

3 Pitetti R, Singh S, Hornyak D, et al. Complementary and alternative medicine use in children. Pediatr Emerg Care 2001;17:165-9.

4 Impicciatore P, Choonara I, Clarkson A, et al. Incidence of adverse drug reactions in paediatric in/out-patients: a systemic review and metaanalysis of prospective studies. $\mathrm{Br} \mathrm{J}$ Clin Pharmacol 2001;52:77-83.

5 Daniels J, Shaw D, Atherton D. Use of Wau Wa in dermatitis patients. Lancet 2002;360:1025.

6 Horowitz RS, Dart RC, Gomez H, et al. Ji Bu Huan toxicity in children. Colorado Morb Mortal Weekly Rep 1993;42:633-6.

7 Lai SM, Lim KW, Wheng HG. Margosa oil poisoning as a cause of toxic encephalopathy. Singapore Med J 1990:31:463-5.

8 Moore C, Adler R. Herbal vitamins: lead toxicity and developmental delay. Pediatrics 2000;106:600-2.

9 Steenkamp V, Stewart MJ, Zuckerman M. Clinica and analytical aspects of pyrrolizidine poisoning caused by South African traditional medicines. Ther Drug Monit 2000;22:302-6.

10 Ernst E. Serious adverse effects of unconventional therapies for children and adolescents: systematic review of recent evidence. Eur $\rfloor$ Pediatr 2003; 162:72-80.

11 MCA. Safety of herbal medicinal products. July 2002; (www.mca.gov.uk)

12 Tomassoni AJ Simone K. Herbal medicines for children: an illusion of safety? Curr Opin Pediatr 2001;13:162-9.

13 Barnes J, Anderson LA, Phillipson JD. St John's wort (hypericum perforatum L.): a review of its chemistry, pharmacology and clinical properties. J Pharmacy Pharmacol 2001;53:583-600. 
14 Ramsay HM, Goddard W, Gill S, et al. Herbal creams used for atopic eczema in Birmingham UK illegally contain potent corticosteroids. Arch Dis Child 2003:88:1056-7.

15 Geiling EMK, Cannon PR. Pathological effects of elixir of sulphanilamide (diethylene glycol) poisoning. JAMA 1938;111:919-26.
16 Okuonghae HO, Ighogboja IS, Lawson JO, et al. Diethylene glycol poisoning in Nigerian children. Ann Trop Paediatr 1992;12:235-8.

17 Hanif M, Mobarak MR, Ronana A, et al. Fatal renal failure caused by diethylene glycol in paracetamol elixir: the Bangladesh epidemic BMJ 1995;311:88-91.

\section{Detection of leptospirosis in India}

\section{$J$ M Vinetz}

\section{A commentary on the paper by Karande et al}

eptospirosis is a zoonotic disease of global significance. ${ }^{1}$ In recent years, -clinicians and epidemiologists have given increasing attention to this disease, with particular focus on two features: its epidemic potential; and severe manifestations, particularly pulmonary haemorrhage. ${ }^{23}$ However, in leptospirosis endemic regions, one quarter of patients (or more) presenting with simple fever have serological results suggesting the diagnosis of acute leptospirosis. Severe leptospirosis seems to be the tip of the iceberg of leptospiralinfection: most peopleinfected by Leptospira seem to have either have simple, undifferentiated fever (fever without focus) or subclinical illness. ${ }^{4}$

Fever is a cardinal manifestation of illness and is a common clinical complaint. In industrialised countries, an undifferentiated febrile illness is often referred to a "viral syndrome" or a "flulike illness", with the expectation that it will resolve itself. In the developing world, depending on locale, an undifferentiated fever may be called "dengue" or "malaria", or depending on the verve of the investigator, a "rickettsial" or "ehrlichial" illness, etc. Regardless of geographic context, however, most often the diagnosis of an undifferentiated fever is on the basis of clinical observation without precise documentation by laboratory, and treatment is symptomatic or specific antimicrobial therapy provided empirically. I would suggest that the term "flu-like illness" is a misnomer and should simply be abandoned as dangerous and the result of fuzzy thinking.

What really is meant by "flu-like illness"? To this author, an influenzalike illness is characterised by the onset of general symptoms such as fever, headache, myalgia, arthralgia, accompanied by upper or lower respiratory symptoms such as sore throat, nasal congestion, and cough. While influenza has a prodrome indistinguishable from many other acute infections, its archetypal manifestations are respiratory. Therefore, regardless of geographic location, to describe fever accompanied by general complaints, without respiratory symptoms, as "flulike" or "viral syndrome" is fraught with hazard and should prompt consideration of other diagnostic possibilities. The underlying meaning of "flu-like illness" is profoundly important, however, particularly today in the era of bioterrorism (for example, pulmonary anthrax which starts out as an undifferentiated fever, later progressing to pulmonary manifestations) and the severe acute respiratory syndrome (SARS). One can only judge with apprehension the next influenza season when many true "flulike" syndromes present to hospital!

\section{"An outbreak of febrile illness occurred in the context of seasonal flooding in Mumbai"}

So it was the diagnostic importance of undifferentiated fever that motivated Karande et al to study leptospirosis in Mumbai, as reported in this issue of the Archives. ${ }^{5}$ The authors took advantage of an outbreak of febrile illness that occurred in the context of seasonal flooding in Mumbai. As is typical with outbreaks of undifferentiated fever, ${ }^{2}{ }^{6}$ public health authorities thought that the outbreak was a "viral" or "dengue-like" illness. When diagnostic testing showed no evidence of dengue virus transmission, other diagnostic possibilities were considered; among them, for some reason not described by the authors, leptospirosis. During a six week period following the Mumbai flood of July 2000, public health authorities in Mumbai issued a directive to admit all patients reporting to its public hospitals with undifferentiated fever and study them for leptospirosis. The paediatrics department at the authors' institution admitted 53 children aged 1 month to 12 years of age with suspected leptospirosis. About one third had serological results suggesting acute leptospirosis. Of equal importance, there were a number of other final diagnoses in these patients, including malaria and
18 O'Brien KL, Selanikio JD, Hecdivert C, et al. Epidemic of paediatric deaths from acute renal failure caused by diethylene glycol poisoning. JAMA 1998;379:1175-80.

typhoid. The risk of leptospirosis rose with age; most cases were 6-12 years old. Four clinical features seemed to be helpful in distinguishing leptospirosis from other causes of fever: contact with flood water, conjunctival suffusion (conjunctival erythema without discharge), abdominal pain, and rash (maculopapular and erythematous, most prominent on the trunk). The zoonotic origin of infection was not investigated. There were no fatalities; all confirmed leptospirosis cases received intravenous penicillin and recovered without sequelae.

The paper of Karande et al is nominally about leptospirosis but raises a central issue in emerging infectious diseases regarding the importance of undifferentiated fever occurring in an epidemic setting. The authors make specific recommendations about the importance of working up patients who come into contact with flood waters, and that children ought to avoid playing in and walking through flood waters. More important for public health, there needs to be a general awareness and deeper understanding of the concept of undifferentiated febrile illness. Astute clinicians and well equipped clinical laboratories need to be vigilant in observing and explaining outbreaks of undifferentiated febrile illness. Only in this way can we avoid the intellectual abyss of dismissing such clinical presentations as only "viral" or "flu-like" illnesses, and delay the recognition of important epidemics of known and newly emerging infectious diseases.

\section{Arch Dis Child 2003:88:1033}

Correspondence to: Associate Professor J M Vinetz, Division of Infectious Diseases, Department of Medicine, University of California, San Diego School of Medicine, 9500 Gilman Drive, Mail Code 0640, La Jolla, CA 92039-0640, USA; jvinetz@ucsd.edu

\section{REFERENCES}

1 World Health Organization. Leptospirosis worldwide, 1999. Wkly Epidemiol Rec 1999;74(29):237-42.

2 Trevejo RT, Rigau-Perez JG, Ashford DA, et al. Epidemic leptospirosis associated with pulmonary hemorrhage-Nicaragua, 1995. J Infect Dis 1998; 178: 1457-63.

3 Ko Al, Galvao Reis M, Dourado CMR, et al. Urban epidemic of severe leptospirosis in Brazil. Lancet 1999;354:820-5.

4 Ashford DA, Kaiser RM, Spiegel RA, et al. Asymptomatic infection and risk factors for leptospirosis in Nicaragua. Am J Trop Med Hyg 2000;63:249-54.

5 Karande S, Bhatt M, Kelkar A, et al. An observational study to detect leptospirosis in Mumbai, India, 2000. Arch Dis Child 2003;88:1070-5.

6 Sanders EJ, Rigau-Perez JG, Smits HL, et al. Increase of leptospirosis in dengue-negative patients after a hurricane in Puerto Rico in 1996. Am J Trop Med Hyg 1999;61:399-404. 